\title{
Current-voltage Characteristics of Water-adsorbed Imogolite Film
}

\author{
Jaehong Park, Jungwoo Lee, Sunyoung Chang, Taehee Park, Bongwoo Han, Jin Wook Han," and Whikun Yi*

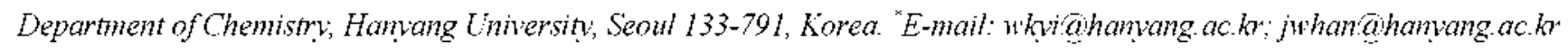 \\ Received March 10, 2008
}

\begin{abstract}
Electric current flow was observed through imogolite film when imogolite $\left((\mathrm{HO})_{3} \mathrm{Al}_{2} \mathrm{O}_{3} \mathrm{SiOH}\right)$ was exposed to water molecules and connected to extemal electrodes. Current flow was due to the bound water on the surface of imogolite. Current flow increased as the $\mathrm{pH}$ of the water decreased. The current-voltage (I-V) measurements from a field effective transistor (FET) using $\mathrm{H}_{2} \mathrm{O} /$ imogolite film revealed that the current carrier in $\mathrm{H}_{2} \mathrm{O}$ / imogolite had p-type characteristics, i.e. the carrier was probably $\mathrm{H}^{-}$. The possible mechanism for current transportation in imogolite/water was also suggested in this paper.
\end{abstract}

Key Words : Imogolite. Field effect transistor. pH. I-V character

\section{Introduction}

Inogolite is a naturally occurring hydrous aluminosilicate found in soil of volcanic origin polymer with a chemical formula of $(\mathrm{HO})_{3} \mathrm{Al}_{2} \mathrm{O}_{3} \mathrm{SiOH}^{1}$ It formis hollow tubes with an external diameter of $2 \mathrm{~lm}$ with typical lengths ranging from about $400 \mathrm{~nm}$ to several micrometers. The tube walls consist of curved gibbsite-like sheets with $\mathrm{SiOH}$ groups on the inside and $\mathrm{AlOH}$ groups on the outside. According to our previous results. ${ }^{2}$ imogolite behaved like an insulator under vacuum. Upon the adsorption of several gases and organic compounds such as $\mathrm{O}_{-}, \mathrm{N}_{2}, \mathrm{Ar}$, benzene, ethanol and pyridine. current flow through inogolite was not observed. It was only under water exposure that the current was observed. These results suggest that current carriers were formed on the surface of inogolite after adsorption of water molecules.

Surface hydroxyls of imogolite have the ability to lose or gain protons from aqueous solution and hence to change the surface charge. At low $\mathrm{pH}$ values, the net charge of the surface is positive and becomes negative at very high $\mathrm{pH}$ values. This can be shown by the following two chemical reactions:

$$
\begin{array}{ll}
\equiv \mathrm{AlOH}+\mathrm{H}^{+} \Leftrightarrow \equiv\left[\mathrm{AlOH}_{2}\right]^{+} & \mathrm{K}_{\mathrm{a}, 1} \\
\equiv \mathrm{AlOH} \Leftrightarrow \equiv \mathrm{AlO}^{-}+\mathrm{H}^{+} & \mathrm{K}_{\mathrm{a}, 2}
\end{array}
$$

The $\mathrm{pH}$ value where the net charge is zero. i.e., when $\left[\mathrm{AlOH}_{2}\right]^{+}=\mathrm{AlO}^{-}$, is called the $\mathrm{pH}$ of point-of zero charge $(\mathrm{pH}(\mathrm{PZC})$ ). For pure inogolite this $\mathrm{pH}$ is about 9 or maybe even somewhat higher. ${ }^{3}$ Below a $\mathrm{pH}=9$ the positively charged surface species $\left[\mathrm{AlOH}_{2}\right]^{+}$predominates. This species is believed to have a role in surface conduction.

In this paper, we report the surface conduction properties of inogolite dipped in various aqueous solutions with $\mathrm{pH}$ values of 7,5 . and 3 . These conditions create different $\left[\mathrm{AlOH}_{2}\right]^{+}$concentrations below the $\mathrm{pH}(\mathrm{PZC})$ condition. Current-voltage curves (I-V curves) are measured by connecting imogolite film to two gold electrodes. Further. a field-effective transistor (FET) using water/imogolite is constructed to determine the carrier type, i.e., p- or n-type for this system.

\section{Experimental Section}

Imogolite was synthesized with orthosilicate and hydroxyl-aluminum in a low $\mathrm{pH}$ solution by the method developed by Farmer $e t a l$ and Wada $e t a l,{ }^{4,5}$ The bonding and wiring structures of the synthesized imogolite were confimed by IR. TEM. and XRD. The synthesized imogolite was dispersed by sonification in weak acidic water and then spread as a film on a silicon substrate.

To obtain the I-V curve. gold electrodes were formed on both ends of imogolite film by magnetic sputtering in order for the distance between electrodes to be $1.5 \mathrm{~mm}$. The current-voltage was measured with an ampere meter (Keitlley $2400)$ after liquid water was dropped onto the imogolite film. We also constructed an FET using water/imogolite Imogolite contacted with an insulator material $\mathrm{SiO}_{2}$ (18 $\mathrm{nm}$ thickness), which was deposited on a higlly doped silicon back gate by magnetic sputtering (Figure 1).

\section{Results and Discussion}

Figure 1 depicts the schematic layout of the FET architecture device used to measure the I-V curve of wateradsorbed imogolite film. Under vacuum imogolite showed no electrical conductance. It is quite plausible that inogolite is an insulator with a wide-bandgap since the outer and inner sides of imogolite tube, i.e. alumina and silica. are both wide-bandgap insulating materials. However. when imogolite was exposed to water molecules inside a vacuum chamber. current flow was observed as reported in our previous report. ${ }^{2}$ It was believed that current passes through the water molecules adsorbed on ingolite surface.

Our strategy in this experiment was to observe the effect of the $\mathrm{pH}$ of the adsorbed water molecules on conductance. This was necessary to use water drop having different $\mathrm{pH}$ values as shown in Figure 1. Each Au electrode was connected with the water drop. Therefore, the measured current

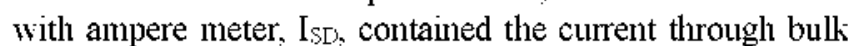
water molecules as well as the current through water molecules adsorbed on imogolite. It was necessary to distinguish 


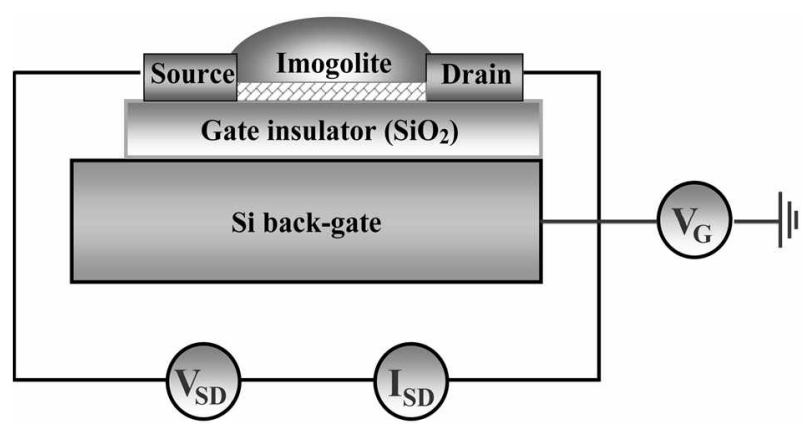

Figure 1. Schematic of experimental set-up used to measure I-V curve of water adsorbed onto inogolite filhn.

between the effect of adsorbed and bulk water molecules on current flow. To measure the current through only the bulk water molecules. we made the device only without the imogolite film at the same condition. The measured $\mathrm{I}_{\mathrm{SL}}$; with the imogolite film between the electrodes was always higher (20-150 times) than the $I_{S D}$ without the imogolite film at the same experimental condition. For example, the $\mathrm{I}_{\mathrm{SD}}$ at $\mathrm{pH}=$ $7, \mathrm{pH}=5$, and $\mathrm{pH}=3$ were measured 177. 272. $7170 \mu \mathrm{A}$. respectively. with the existence of inogolite film. On the while, the corresponding $I_{S D}$ values without the film were much lower and to be $6.47,11.6$, and $56.0 \mu \mathrm{A}$. The former value was the summation of two current values, i.e. the current passing through the water molecules adsorbed on imogolite and the current passing through the bulk water molecules. It appeared that the protons in the bulk water play a smaller role in the transport of current compared to the water molecules bounded on the imogolite surface.

Figure 2 is an atomic force microscopy (AFM) picture of the imogolite sediment after dispersion on Si substrate. The sediment consisted mainly of fibers, which were aligned in bundles. This imogolite sample was thought to contain a significant amount of impurities such as proto-imogolite.

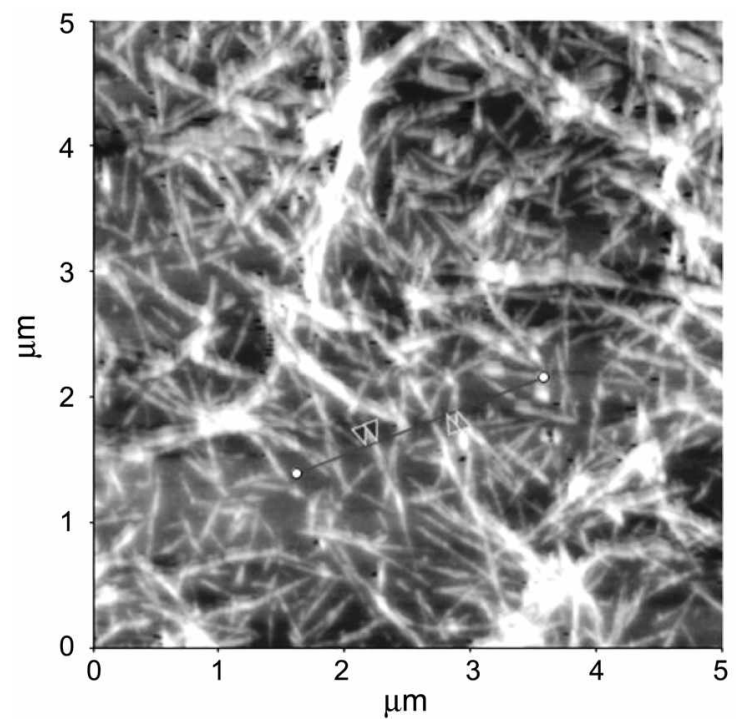

Figure 2. AFM image of inogolite sediment obtained by centrifugation of the as-prepared imogolite.

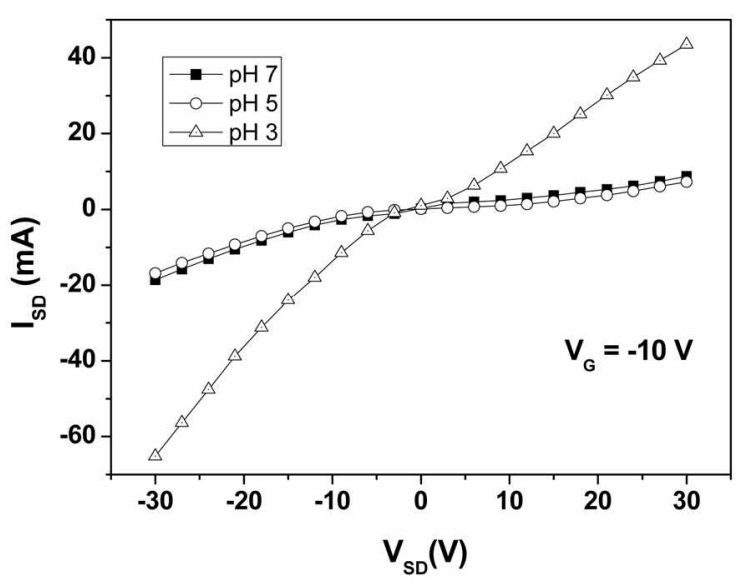

Figure 3. I-V curves of water adsorbed on mogolite film at $\mathrm{pH}=$ 7,5 , and 3 at $V_{u}=10 \mathrm{~V}$.

allophane. since fine granular morphology suggested an allophane structure.

Figure 3 shows the I-V (IS工 is $V_{S D}$ ) curves of the imogolite film dipped in water drop at different $\mathrm{pH}$ values. For comparison under the same conditions. we used the same imogolite device to compensate for experimental error. A slight change in current was observed when the $\mathrm{pH}$ was decreased from 7 to 5 . However, the current increased 2-3 times at $\mathrm{pH}=3$. It is difficult to explain these current values since there are no published data on the conduction of water molecules adsorbed onto imogolite. In 2006. Lee et al. measured conductivity of polypyrrole-coated imogolite by varying the thickness of polypyrrole.

In 1991. Wehrli et al $^{7}$ studied the surface protonation of the different crystallographic planes of kaolinite. Kaolinite is a clay mineral consisting of an extended sheet of two constituents: a silica-type layer of stoichiometric composition $\left(\mathrm{Si}_{4} \mathrm{O}_{10}\right)^{4-}$ and a gibbsite-type layer $(\mathrm{OH})_{6-}-\mathrm{Al}_{4-}(\mathrm{OH})_{2} \mathrm{O}_{4}{ }^{8}$ Its gibbsite structure is similar with the surface structure of imogolite. They examined the $\mathrm{pH}$-dependent protonation of the hydroxyl groups at the basal gibbsite. and proposed that at $\mathrm{pH}<5 \mathrm{Al}-\mathrm{OH}-\mathrm{Al}$ groups at the gibbsite surface are protonated and dominate the overall weathering process of kaolinite. Their computed values of proton density at the gibbsite of kaolinite at $\mathrm{pH}=7.5$. and 3 were about to 0.0 .2 . and $1.8 \mu \mathrm{mol} / \mathrm{m}^{2}$, respectively. In their calculation. the saturation point of protonation was detemined to be 2.0 $\mu \mathrm{mol} / \mathrm{m}^{2}$. The observations made by Welurli et al. can provide some explanations for our results in Figure 3. Assuming that a similar protonation occurred on the imogolite surface at $\mathrm{pH}=3$. most of surface species of imogolite would be covered with positively charged $\left[\mathrm{AlOH}_{3}\right]^{-}$. Furthermore. this species is responsible for the surface conduction observed in Figure 3.

In order to detenmine the carrier type of current in the water/imogolite system. we measured the voltage-current at $\mathrm{pH}=3$ by varying the gate voltage $\left(\mathrm{V}_{\mathrm{G}}\right)$ with the setup shown in Figure 1. FET devices using water/mogolite exhibited p-type characteristics as shown in Figure 4. When the $V_{G}$ was changed from $+10 \mathrm{~V}$ to $-10 \mathrm{~V}$. the current 


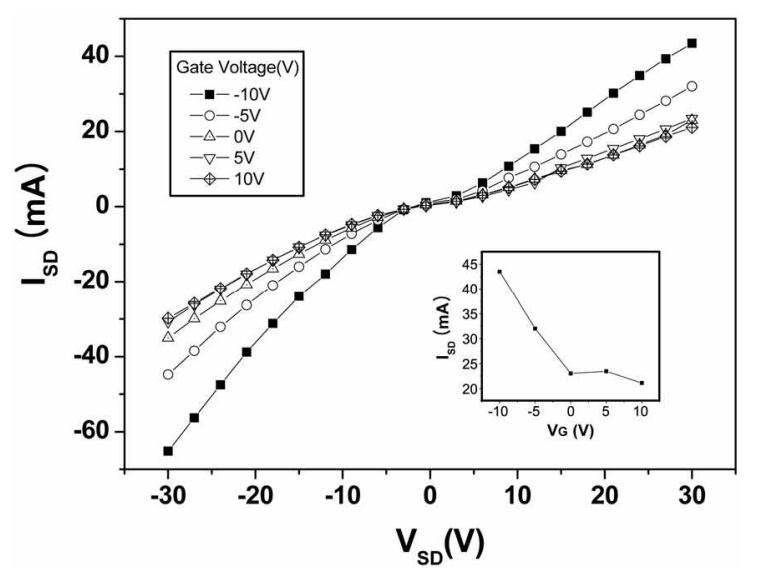

Figure 4. I-V curves of water/mogolite FET device at $\mathrm{pH}=3$ at various gate $\left(\mathrm{V}_{G}\right)$ voltages ranging from -10 to $10 \mathrm{~V}$. Inset is a $I_{S D}$ versus $V_{G}$ plot recorded on the same device at $V_{S D}=30 \mathrm{~V}$.

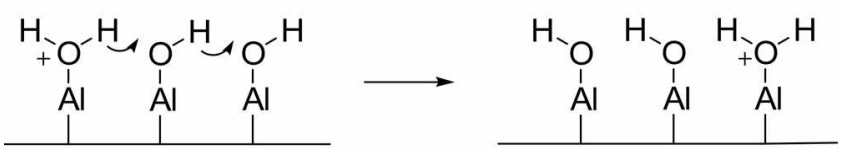

Scheme 1. Suggested mechanism for current transportation in the inogolite/water system

increased gradually from $2 \mathrm{l}$ to $44 \mathrm{~mA}$ at $\mathrm{V}_{\mathrm{SD}}=30 \mathrm{~V}$. (Inset of Fig. 4) The shape of the I-V curves implies that water/ imogolite device behaves like a semiconductor with a band gap in the magnitude of $5.7 \mathrm{eV}$ judging from the flat line around $\mathrm{V}_{\mathrm{SD}}=0 \mathrm{~V}$. The total resistance of this device, which included contact resistances, was calculated to be $1.3 \mathrm{k} \Omega$ for $\mathrm{V}_{\mathrm{G}}=0 \mathrm{~V}$.

Interestingly. similar behavior has been observed in the layered structure of vanadium pentoxide hydrate $\left(\mathrm{V}_{2} \mathrm{O}_{5} \cdot \mathrm{nH}_{2} \mathrm{O}\right)$. It had higher electrical conducticity than of anlydrous orthorhombic $\mathrm{V}_{2} \mathrm{O}_{5}{ }^{1}$ In 1983, Barboux et al. ${ }^{\text {(c) }}$ studied the conductivity of this material in $\mathrm{H}_{\beth} \mathrm{O}$ vapor and investigated the relationship between the changes in conductivity of $\mathrm{V}_{3} \mathrm{O}_{3} \cdot \mathrm{nH}_{2} \mathrm{O}$ with increasing $\mathrm{H}_{2} \mathrm{O}$ vapor pressure. They concluded that the increase in conductivity was due to the $\mathrm{H}^{+}$ in this material. Uchida and Kittaka ${ }^{11}$ extended this study by investigating the electrical properties of $\mathrm{V}_{3} \mathrm{O}_{3} \cdot \mathrm{nH}_{3} \mathrm{O}$ by measuring the impedance as a function of $\mathrm{H}_{2} \mathrm{O}$ vapor pressure.

The imogolite/water system at $\mathrm{pH}=3$. in which most of the imogolite surface was believed to be covered with $\left[\mathrm{AlOH}_{3}\right]^{+}$species. showed p-type seniconductor characteri- stics. Even though it is not clear what species are to the actual current carriers, a proton $\left(\mathrm{H}^{+}\right)$is thought to be a plausible candidate. In other words. current transfer would occur by the effective motion of a proton. which would be involved in the formation and destruction of bonds through a long chain of hydroxyl groups adsorbed onto imogolite. Therefore. the mechanism for current transportation in imogolite/water system is suggested in Scheme 1 .

\section{Conclusion}

Electric current flow was observed through imogolite when imogolite $\left((\mathrm{HO})_{3} \mathrm{Al}_{2} \mathrm{O}_{3} \mathrm{SiOH}\right)$ was exposed to water molecules. The current flow was believed to be due to the bound water on the surface of imogolite. Higher current flow was observed as the $\mathrm{pH}$ was decreased. According to the results from the FET measurements by varying the gate voltage, we suggest that current carrier was probably a proton $\left(\mathrm{H}^{+}\right)$moving through imogolite surface. The interaction of $\mathrm{H}_{2} \mathrm{O}$ with electrical conditions of imogolite is an interesting subject for further study. since this property might elucidate new properties of the material.

Acknowledgments. This work was supported by the research fund of Hanyang University (HY-2007-I) and one of the authors (J. L.) wishes to thank Brain Korea 21 for award of financial support.

\section{References}

1. Cradwick, P. D. G.; Farmer, V. C.; Russel. J. D.; Masson. C. R: Wada, K. Yoshinaga. N. Katme Phys. Sci. 1972. 240.187.

2. Oh. J.: Chang. S.: Tan1g. J.: Roh. S.: Park. J.: Lee. J.: Sohn1. D.: Y1. W. Tung. Y.: Kiml. S. J. Matert Sci.: Hater. Electront 2007. 18. 893.

3. Su. C.: Harsh, J. B.: Bertsch, P. M. Clays Clay Hiner: 1992. 40. 280.

4. Farmer. V.C.: Adams. M. J; Fraser. A. R.; Pamieri. F. Clay iner: 1983. 18. 459

5. Wada. S.-I. Clan Hinet 1987.35.379

6. Lee. Y: Kim. B.: Y1. W.: Tahahara. A.: Sohn. D. Bull. Konean Chem. Soc. 2006, 27(11). 1815 .

7. Wehrli. B.: Wieland. E.: Furrer. G. Aquatic Sci. 1990, 52.1.

8. Ferris, A. P. Jepson. W. B. J. Colloid huterface Sci. 1975. 51. 245.

9. Sanchez. C.: Babonneau. F.: Morineau. R.: Livage. J.: Bullot. J. Philos. Hag. B 1983. 77.219.

10. Barboux, P; Battier, N;: Morineau. R.; Livage. J. Solid State Ionics 1983. 910, 1073 .

11. Naoki. U.: Shigeharu. K. J. Plys. Chem. 1994, 98, 2129. 